Tropical Agricultural Research \& Extension 17(3 \& 4): 2014

\title{
PERCEIVED IMPROVEMENT STRATEGIES FOR EXTENSION TEACHING METHODS AMONG CASSAVA FARMERS IN EDO STATE, NIGERIA
}

\author{
${ }^{1}$ JJKOkoedo-Okojie DU and VE Ikharea ${ }^{2}$ \\ ${ }^{1}$ Department of Agricultural Economics and Extension Services, University of Benin P.M.B. 1154 Benin City, Nigeria \\ ${ }^{2}$ Research Outreach Department, Extension Division, Rubber Research Institute of Nigeria, P.M.B. 1049 \\ Iyanomo, Benin City. Nigeria
}

Accepted: $10^{\text {th }}$ October 2014

\begin{abstract}
The study assessed the perceived improvement strategies for extension teaching methods, among cassava farmers in Edo state, Nigeria. Data collected from one hundred and fifty (150) cassava farmers through a multi stage sampling procedure by use of questionnaire were analyzed using frequency count. Percentage and correlation was used to determine relationship between variables. The findings showed male (56.0\%) dominance and meetings (89.3\%) were the most preferred source for receiving proven technologies information. All of the respondents suggested improvement in farm and home visits: by regular visits at least once in two (02) weeks; and visit rotated amongst various home/ farms. There is no relationship between the socio economic characteristics of farmers and their adoption of proven technology. The findings show that meetings were the most used channels for information dissemination (89.3\%). Consequently, extension visits to the farmers should be sustained after a seemingly success of technology adoption, as this will help to reinforce the message and enhance the accuracy of implementation of the technology packages.
\end{abstract}

Keywords: communication channel, cassava farmers, adoption, perceived improvement strategies.

\section{INTRODUCTION}

Cassava is amajor source of calories for roughly two out of every five Africans. Cassava production in Nigeria is increasing speedily because of the prospect or opportunities associated with its production and marketing. Cassava is amenable to agronomic practices and has a high yield potential. Under good soil and climatic condition, it can perform better than other crops. Apart from its high productivity and calorific content, cassava has other relevant advantages such as being season bound and its ability to store well in soil for several months (Alabi and Oviasogie, 2005). Presently in Nigeria, Cassava production is in the hands of small holder farmers on marginal and sub marginal land in the humid and sub humid tropics (Food and Agriculture OrganisationFAO) and international fund for agriculture development (FAO and IFAD, 2001). This implies that the production of the crop is still, on subsistence level as larger proportion of the cassava produced in the country is consumed locally. This situation could be attributed to low utilization of proven agricultural technologies; a situation that rises questions on cassava farmers' access to technologies. Development and production of relevant and appropriate technologies is one of the pre-requisite for sustainable agriculture. Others according to Agwu and Adeniran (2009) include dissemination of these technologies as well as their eventual adoption and practical use by the farmers. According to Ekumankama (2000) sustainable agricultural development will continue to elude Nigeria unless appropriate innovations are effectively communicated to the farming population. Yahaha and Olajide (2000) noted that dif-

\footnotetext{
*Corresponding author: ibhadedavid@yahoo.com
} 


\section{D.U OKOEDO-OKOJIE AND V.E. IKHAREA PERCEIVED IMPROVEMENT STRATE-}

fusion and adoption of innovations remains the back bone of the expected development in agriculture. The goal of communication through extension teaching is the acceptance of information (the sender message) by the receiver. If the receiver understands the meaning of a message that asks for action, but fails to act, the goal of communication is not achieved. Hence successful communication to a greater extent depends on the receiver. In agriculture, a lot of resources are needed to communicate proven technologies to farmers through extension teaching methods. The particular channel for use is majorly determined by extension agents as Benor and Baxter (1984) had noted that without extension guidance, farmers often are unable fully to exploit the opportunities available to them. The use of right extension teaching method and communication channels is important in effective information dissemination, if the receiver must make a meaning out of the message received. Beyond putting the right teaching method and to use, the users or receivers perception of the source of information and method of knowledge transfer is very important. The receiver's attitude to the message can be dependent on his/her perception about the channel or method. The form in which proven technology information reach farmer can be related to their acceptance and perceived functionality of extension teaching methods through which information is received. Farmers' adoption and continuous adoption of technologies and practice through any particular methods call for their perceived improvement strategies of such methods that make it useable for proven agricultural information sourcing. This study was therefore carried out to access perceived improvement strategy for extension teaching methods among cassava farmers in Edo state Nigeria. Specific objectives were to:

examine the socio economic characteristics of the farmers;

identify respondents information sources and cassava technologies adopted;

determine respondents perceived improvement strategies for extension teaching methods .
A null hypothesis was set that there is no significant relationship between information sources used by farmers and their adoption of cassava technologies.

\section{MATERIALS AND METHODS}

The study was carried out in Edo state. Edo state is an inland state in South South Nigeria, located in the tropical rain forest zone. The state covers an area of $17,802 \mathrm{~km}^{2}$. The study was centered in three local government areas of the state: Owan west, Esan central and IkpobaOkhalocal government areas, where cassava production is prominent. The state has three (3) agricultural zones: North, Central and South zones.

A multi stage sampling procedure was used in selecting respondents for the study. The first stage was the random selection of one local government from each of the three(3) agricultural zone, the second stage was the selection of five (5) villages from each local government area making a total of fifteen (15) villages and the third stage was to select 10 non-contact farmers from each village making a total of 10 farmers per village, making a total of 150 farmers who were randomly selected. The data for the study were collected using a well structured questionnaire, and complement by interview schedule. Data were analyzed using frequency counts, percentages and correlation for hypothesis testing.

\section{RESULTS AND DISCUSSION}

\section{Socio Economic Characteristics of the Re- spondents}

The results showed that majority $(78.7 \%)$ of the respondents were between 50 and 59 years old, with a mean age of 55 years. The findings indicate that most of the respondents are elderly and therefore have a good knowledge of extension teaching methods, communication channels and cassava technology adoption. This finding is similar to African Networks for 
Environment and Economic Justice, ANEEJ (2004) that farmers in Nigeria are mostly above 50 years. The results also showed that majority $(96.00 \%)$ of the farmers were married. This status implies that they have family members to cater for, so they are likely to desire more information towards increasing their income earning capacity through cassava farming. This might ultimately improve their standard of living, a fact that may suggest a high degree of level headedness and a great capacity for sound rational decisions among the farmers. This factor is likely to encourage the sustainability of adoption decisions. Ejembi et al. 2006), 61.4\% had secondary education. This means respondents are literate taking the baseline of literacy to be primary education, an indication that they had the capacity and the ability to receive and utilize agricultural information, if appropriate extension teaching methods and communication channels are in place. The modal farming experience was between 11 to 15 years and this formed the greater proportion $(69.3 \%)$. According to Igben (1988), a long farming experience is an advantage for respondents' preference for extension teaching method and communication channels and for increase farm productivity. A long farming experience aids increased farm productivity, in that it encourages rapid adoption of new farm practices and improves specialization. Also, 66.67\% had between 5 and 7 persons in their household. This finding implies that farmers do not cultivate crops only to maximize profit, but also to provide food for their family consumption. The modal household size is large enough an indication that respondents use technologies appropriately communicated for improved production for family upkeep. From the table 1 , we see that majority $(70.7 \%)$ of the farmers had up to between 2 and 3 ha of cassava farms. This result shows that the study area comprises of small-scale farmers. The size of farm cultivated by farmer is a function of production pressure, family size, labour availability, financial background and experience and experience of farmer (Imonikhe, 2004). All (100\%)of the respondents were full time farmers. This implies that farming is their sole occupation, thus they would be highly receptive to adopt technology, if adequately and indication that respondents use technologies appropriately communicated for improved production for family upkeep. From the table 1, we see that majority $(70.7 \%)$ of the farmers had up to between 2 and 3ha of cassava farms. This result shows that the study area comprises of small-scale farmers. The size of farm cultivated by farmer is a function of production pressure, family size, labour availability, financial background and experience and experience of farmer (Imonikhe, 2004). All (100\%)of the respondents were full time farmers. This implies that farming is their sole occupation, thus they would be highly receptive to adopt technology, if adequately and for getting loan. The table also showed that $54.7 \%$ of the cassava farmers were involved in production, $20 \%$ were involved in processing of cassava $24 \%$ are into marketing of the product. This implies that they are likely more inclined to receiving information and adopt technology on production farming practices, and could be a reflection of membership of cooperative societies.

TABLE 1: Distribution of respondents by Socio economic characteristics $(n=150)$

\begin{tabular}{llll}
\hline \multicolumn{1}{c}{ VARIABLE } & Percentage & Mean \\
\cline { 2 - 3 } & Frequency & 12.0 \\
$40-49$ & 18 & 78.7 \\
$50-59$ & 118 & 9.3 & 55 \\
$60 \&$ above & 14 & & \\
Gender & & 44.00 & 56.00 \\
Female & 66 & 84 & \\
Male & & & \\
\hline
\end{tabular}


129 D.U OKOEDO-OKOJIE AND V.E. IKHAREA PERCEIVED IMPROVEMENT STRATE-

\begin{tabular}{|c|c|c|c|}
\hline Marital Status & & & \\
\hline Single & 2 & 1.3 & \\
\hline Married & 144 & 96.0 & \\
\hline Divorced & 2 & 1.4 & \\
\hline Separated & 2 & 1.3 & \\
\hline Education & & & \\
\hline Primary & 56 & 37.3 & \\
\hline Secondary & 92 & 61.4 & \\
\hline Tertiary & 2 & 1.3 & \\
\hline Farming experienc & & & \\
\hline$<5$ & - & - & \\
\hline $6-10$ & 30 & 20.0 & \\
\hline $11-15$ & 104 & 69.3 & \\
\hline $16-20$ & 16 & 10.7 & \\
\hline$>20$ & & & \\
\hline Household size & & & \\
\hline $4 \&$ below & 36 & 24.0 & \\
\hline $5-7$ & 100 & 66.7 & \\
\hline $8-10$ & 14 & 9.3 & 6 \\
\hline Farm size(Ha) & & & \\
\hline $1 \&$ below & 2 & 1.3 & \\
\hline $1.1-2.0$ & 8 & 5.3 & \\
\hline $2.1-4.0$ & 106 & 70.7 & \\
\hline $4.1-6.0$ & 34 & 22.7 & \\
\hline Farming status & & & \\
\hline part-time & - & - & \\
\hline full time & 150 & 100.0 & \\
\hline Annual income & & & \\
\hline 50,000 \& below & 4 & 2.7 & \\
\hline $50,001-100,000$ & - & - & \\
\hline $100,001-150,000$ & 6 & 4.0 & \\
\hline $150,001-200,000$ & 60 & 40.0 & \\
\hline$>200,000$ & 80 & 53.3 & \\
\hline Association Memb & & & \\
\hline Cooperatives & 82 & 54.7 & \\
\hline village association & 40 & 26.7 & \\
\hline age group & 14 & 9.3 & \\
\hline Unions & 14 & 9.3 & \\
\hline
\end{tabular}




\section{Cassava information sources used by farmers}

Under individual method, Farm and home visits $(70.7 \%)$ had the highest response. This showed that most farmers receive their farm information through interpersonal methods. An indication that interpersonal methods were most frequent methods used by the extension agents in disseminating agricultural information to farmers, probably because of the possibilities of immediate feedback and multiplier effects of these methods. Farmers majorly obtain information from only 2 channels under group teaching method; group discussion $(77.33 \%)$ and meetings $(89.33 \%)$. This result could be expected as the respondents (Table 1) are co-operators and cooperative society's uses group discussion and meetings in reaching members with information. Table 2 showed that farmers do not make use of any channel under the mass method (internet, poster, campaign/exhibition). This could be attributed to the fact that respondents may not be disposed to the skills required for operation; also it is an indication that mass method is not commonly used for agricultural information dissemination in the study area. The lack of interest in the use of newspaper, posters, bulletins, television, radio, leaflets/ pamphlets by the farmers is as a result of the fact that they are already exposed to home visits, group discussion and demonstration.

\begin{tabular}{lll}
\multicolumn{2}{l}{ Table 2 Cassava Information Sources Used } & \\
\hline Extension teaching method & & Percentage \\
\hline & *Fequency & \\
Individual methods & & 70.7 \\
Home/Farm visits & 106 & 69.3 \\
Friends/Neighbours & 104 & 13.3 \\
GSM/Telephone & 20 & \\
Group methods & & 89.3 \\
Meetings & 134 & 77.3 \\
Group discussions & 116 & 6.7 \\
Demonstration & 10 & 2.7 \\
Workshop & 74 & 77.3 \\
Lectures & 116 & \\
Mass methods & & - \\
Internet & - & - \\
Campaign/Exhibition & - & 4.0 \\
Newspaper & 6 & - \\
Posters & - & 1.3 \\
Bulletins & 2 & 1.3 \\
Television & 2 & 1.3 \\
Radio & 2 & - \\
Leaflets/Pamphlets & - & \\
\hline
\end{tabular}

Table 3 showed agricultural information adopted by respondents through communication channels. Respondents adopted the use of clean planting materials and crop rotation techniques (96.0\%) intercropping (93.3\%), sources of planting materials and source of credit $(74.7 \%)$, sources of fertilizer and information on farm labour management ( $73.3 \%$ ). This result is a reflection that respondents mainly adopted production innovation; this could be expected as majority (54.7\%) of the respondents was into cassava production. (Table1). This high adoption, among the respondent, could be attributed to the fact that majority are educated with small farm sizes that calls for improvement of production as Omonona et al 2006, also Amao and Awoyemi (2009) had observed that years of education and land size are significant determinant in adoption of farm technologies. This result is an indication that extension teaching methods are being used by respondents and could assist their capacity for perceived improvement strategies.

Table 3: Agricultural Information Adopted through Extension teaching methods and Communication Channels

\begin{tabular}{|c|c|c|}
\hline Technologies & ${ }_{y}^{*}$ frequenc & $\begin{array}{l}\text { Percentage } \\
(n=150)\end{array}$ \\
\hline Improved varieties & 24 & 16.0 \\
\hline Crop spacing & - & - \\
\hline Pesticide Application & 6 & 4.0 \\
\hline $\begin{array}{l}\text { Manure/Fertilizer Ap- } \\
\text { plication }\end{array}$ & 2 & 1.3 \\
\hline $\begin{array}{l}\text { Post harvest storage } \\
\text { methods }\end{array}$ & 6 & 4.0 \\
\hline $\begin{array}{l}\text { Sources of planting } \\
\text { materials }\end{array}$ & 112 & 74.7 \\
\hline Sources of other inputs & 110 & 73.3 \\
\hline Weeding & 92 & 61.3 \\
\hline Inter-cropping/crop rot & 140 & 93.3 \\
\hline Use of clean planting & 144 & 96.0 \\
\hline
\end{tabular}




\section{D.U OKOEDO-OKOJIE AND V.E. IKHAREA PERCEIVED IMPROVEMENT STRATE-}

\begin{tabular}{|c|c|c|}
\hline \multicolumn{3}{|l|}{ Demonstrations } \\
\hline Should be very practical & 150 & 100.0 \\
\hline The farmers should be involved in it & 150 & 100.0 \\
\hline \multicolumn{3}{|l|}{ Meetings } \\
\hline Should be reminded of meeting schedule before hand & 150 & 100.0 \\
\hline Should be regular, at least once in two weeks & 150 & 100.0 \\
\hline Indicate the type of meetings & 150 & 100.0 \\
\hline \multicolumn{3}{|l|}{ Group discussions } \\
\hline Should be held; (Group discussion:) & 87 & 58.0 \\
\hline Before planting & 90 & 60.0 \\
\hline During land preparation & 66 & 44.0 \\
\hline During gestation & 138 & 92.0 \\
\hline At harvesting & 141 & 94.0 \\
\hline \multicolumn{3}{|l|}{ Lectures } \\
\hline Should be regular, at least once in two weeks & 129 & 86.0 \\
\hline Should be in medium that the farmers understand & 144 & 96.0 \\
\hline Should be more interactive & 129 & 86.0 \\
\hline \multicolumn{3}{|l|}{ Workshop } \\
\hline Should be frequent, at least once in two weeks & 144 & 96.0 \\
\hline Should be very practical & 132 & 88.0 \\
\hline The farmers should be involved & 102 & 68.0 \\
\hline
\end{tabular}

PERCEIVED IMPROVEMENT STRATEGIES FOR EXTENSION TEACHING METHODS

From the table 4, all (100.00\%) of the respondents suggested that "home and farm visits should be regular at least once in two weeks", and "visits should be rotated amongst various homes/farms". This is an indication that farmers and farm families desire greater level of intimacy with extension agents to discuss better, common and private interest without distraction and interruption. Also, all (100\%) of the respondents suggested that "demonstrations should be very practical and farmers should be involved in it", "Farmers should be reminded of meeting schedule beforehand", "meetings should be regular, at least once in two weeks." This implies a high interest in the improvement and sustenance of demonstrations, it indicates a high level of group appeal, compactibility with prevailing post socio-cultural values and beliefs and complexity in relation to perceived relative difficulty to use and understand. This result agrees with Adeboyoet al (2003) that compactibilty and complexity of message enhances acceptability of by target audience. Meetings also recorded $100.0 \%$ response in reminder of meeting schedule in advance, regularly at least every two weeks.

\begin{tabular}{|c|c|c|}
\hline \multicolumn{3}{|l|}{$\begin{array}{l}\text { Perceived Improvement Strategies for Extension Teach- } \\
\text { ing Methods }\end{array}$} \\
\hline Individual methods & \multicolumn{2}{|c|}{${ }^{*}$ Frequen } \\
\hline \multicolumn{3}{|l|}{ Home/Farm visits } \\
\hline Visit should be regular, at least once in two weeks & 150 & 100.0 \\
\hline Visits should be rotated amongst various Homes/farm & 150 & 100.0 \\
\hline \multicolumn{3}{|l|}{ GSM/Telephone } \\
\hline $\begin{array}{l}\text { Should be used to communicate meeting/workshop sched- } \\
\text { ule. (place and time) }\end{array}$ & 99 & 66.0 \\
\hline \multicolumn{3}{|l|}{ Group methods } \\
\hline \multicolumn{3}{|l|}{ Demonstrations } \\
\hline Should be very practical & 150 & 100.0 \\
\hline The farmers should be involved in it & 150 & 100.0 \\
\hline \multicolumn{3}{|l|}{ Meetings } \\
\hline Should be reminded of meeting schedule before hand & 150 & 100.0 \\
\hline Should be regular, at least once in two weeks & 150 & 100.0 \\
\hline Indicate the type of meetings & 150 & 100.0 \\
\hline \multicolumn{3}{|l|}{ Group discussions } \\
\hline Should be held; (Group discussion:) & 87 & 58.0 \\
\hline Before planting & 90 & 60.0 \\
\hline During land preparation & 66 & 44.0 \\
\hline During gestation & 138 & 92.0 \\
\hline At harvesting & 141 & 94.0 \\
\hline \multicolumn{3}{|l|}{ Lectures } \\
\hline Should be regular, at least once in two weeks & 129 & 86.0 \\
\hline Should be in medium that the farmers understand & 144 & 96.0 \\
\hline Should be more interactive & 129 & 86.0 \\
\hline \multicolumn{3}{|l|}{ Workshop } \\
\hline Should be frequent, at least once in two weeks & 144 & 96.0 \\
\hline Should be very practical & 132 & 88.0 \\
\hline The farmers should be involved & 102 & 68.0 \\
\hline
\end{tabular}

\begin{tabular}{lll}
\hline $\begin{array}{l}\text { Perceived Improvement Strategies for Extension Teaching } \\
\text { Method (cont.) }\end{array}$ & $\begin{array}{l}\text { Frequency } \\
\text { age }\end{array}$ & percent- \\
\hline Radio & & 38.0 \\
Programs should be aired at least once in two weeks & 54 & 96.0 \\
Increase the number of agricultural programs aired. & 144 & \\
Television & & 98.0 \\
Programs should be aired in languages the farmers understand & 147 & 36.0 \\
programs should be regular, at least once in two weeks & 54 & 84.0 \\
Programs shown on T.V should include demonstrations & 126 & \\
Internet & & 92.0 \\
Use of internet and ICTs in disseminating information during & 138 & \\
meetings & & 94.0 \\
Should be surfed regularly to seek for; & 141 & 96.0 \\
New prices & 144 & 86.0 \\
New market & 129 & 86.0 \\
New concepts & 129 &
\end{tabular}


Mass media methods (print)

\begin{tabular}{|c|c|c|}
\hline \multicolumn{3}{|l|}{ Newspaper } \\
\hline $\begin{array}{l}\text { Agricultural programs should be printed in lan- } \\
\text { guages the farmers understand. }\end{array}$ & 60 & 40.0 \\
\hline $\begin{array}{l}\text { Programs should be advertised using illustrative } \\
\text { diagrams. }\end{array}$ & 120 & 80.0 \\
\hline Programs should be published weekly & 141 & 94.0 \\
\hline \multicolumn{3}{|l|}{ Posters } \\
\hline Should be frequently used & 138 & 92.0 \\
\hline $\begin{array}{l}\text { Should include pictures that the farmers can under- } \\
\text { stand }\end{array}$ & 144 & 96.0 \\
\hline Should be simple and clear & 141 & 94.0 \\
\hline $\begin{array}{l}\text { Success of technology adoption by other farmers } \\
\text { should be included }\end{array}$ & 141 & 94.0 \\
\hline \multicolumn{3}{|l|}{ Leaflets/Pamphlets } \\
\hline Should be simple enough & 96 & 64.0 \\
\hline Should be distributed at meetings/group discussions & 120 & 80.0 \\
\hline \multicolumn{3}{|l|}{ Bulletins } \\
\hline Should be released at least once in two months & 129 & 86.0 \\
\hline \multicolumn{3}{|l|}{ Mass media (Campaign/Exhibition) } \\
\hline Farmers should be involved in campaign/exhibition & 138 & 92.0 \\
\hline $\begin{array}{l}\text { Success of technology adoption by other farmers } \\
\text { should be included }\end{array}$ & 138 & 92.0 \\
\hline
\end{tabular}

RELATIONSHIP BETWEEN EXTENSION TEACHING METHOD USED AND ADOPTION OF CASSAVA TECHNOLOGY

Table 5 shows the correlation between extension teaching method and communication channels used by respondent and the adoption of cassava technology. The result shows that ten of the channels have a significant influence on adoption.

Home/farm visits: The table reveals that the correlation between home/farm visits and adoption is 0.521 which is positive. The positive result implies that, the more information received through this channel, the more the farmers are likely to adopt or apply the information. This suggests that, farmers rely on or trust information received via this channel.

Demonstration: The table showed that the correlation between demonstration and adoption is 0.810 which is positive. The positive result implies that, the more information received through this channel, the more the farmers are likely to adopt or apply the information. This suggests that, farmers rely on or trust information received via this channel.

Hypothesis: There is no significant relationship between extension teaching method and communication channels used by respondents and adoption of cassava technologies.

None of the extension teaching methods and communication channels used was significant to the respondents adoption of technologies. However, farm and home visits $(\mathrm{r}=0.521)$, meeting $\quad(\mathrm{r}=0.211)$, group discussion $(\mathrm{r}=0.750)$, were all significant at 0.01 level. The positive correlation, is an indication that the more respondents are exposed to these for proven farm innovation and practices the more they are likely to adopt or apply the information. The negative sign for television means that the more respondent are exposed to farm practices information on television, the less they will adopt such innovations, an indication that cassava farmers in the study area are not disposed in this regard

Table 5 Relationship between Extension teaching methods and Communication Channels Used and Adoption of Farm Technologies (correlations)

\begin{tabular}{lll}
\hline Channels & $\begin{array}{l}\text { Coefficient } \\
\text { (r) }\end{array}$ & $\begin{array}{l}\text { Prob. } \\
\text { Level }\end{array}$ \\
\hline Radio & 0.011 & 0.90 \\
Television & -0.001 & 0.99 \\
Friends/Neighbours & 0.098 & 0.23 \\
Home/Farm visits & $0.521^{* *}$ & 0.00 \\
Demonstration & 0.110 & 0.12 \\
Meetings & $0.211^{* *}$ & 0.01 \\
Group discussions & $0.703^{* *}$ & 0.00 \\
Newspaper & 0.145 & 0.08 \\
Campaign/Exhibition & 0.053 & 0.00 \\
Posters & $0.018^{* *}$ & 0.25 \\
Workshop & $0.782^{* *}$ & 0.00 \\
GSM/Telephone & 0.069 & 0.40 \\
Leaflets/Pamphlets & 0.137 & 0.10 \\
Bulletins & 0.056 & 0.28 \\
Lectures & $0.750^{* *}$ & 0.00 \\
Internet & 0.102 & 0.06 \\
\hline
\end{tabular}




\section{D.U OKOEDO-OKOJIE AND V.E. IKHAREA PERCEIVED IMPROVEMENT STRATE-}

\section{CONCLUSION}

Cassava farmers perceived that there is need for improvement strategies on extension teaching

Methods to assist them in the sourcing and adoption of proven technologies.

\section{RECOMMENDTION}

Use of mass methods of teaching and communication in disseminating proven cassava technology should be encouraged as this will improve technology adoption by the farmers. Seminars and workshops should be organized for cassava farmers on the use of improved communication channels ( internet, campaign/ exhibition) in disseminating proven technology as this will enable the farmers go on a self learning process thus increase in the adoption of proven technology. Technologies such as crop spacing, manure application and post harvest storage methods with low adoption presently should be repeatedly communicated to the farmers with their suggested improvement strategies in view to enhance adoption

\section{REFERENCES}

ANEEJ 2004 Climate change and poverty sustainable approach in the Niger Delta. A publication of the African Network for Environment and Economic Justice

Adebayo K, Anyanwu AC and Dsiyale AO 2003 Perception of environmental issues by cassava processors in Ogun state, Nigeria; Implications for environmental education. Journal of extension systems 19:103-112

Agwu AE and Adeniran AA 2009 Sources of Agricultural Information used by Arable Crop Farmers in Isale Osun Farm Settlement, Osogbo Local Government Area of Osun State. Journal of Agricultural Extension 13(1): 24-34
Alabi RA and Oviasogie 2005 Cassava production and processing in Nigeria: opportunities and challenges. Agricultural Rebirth for Improved Production in Nigeria. Proceedings of the $39^{\text {th }}$ Annual Conference of the Agricultural Society of Nigeria, held at the University of Benin Benin city, Nigeria Oct.9th-13th:2225

Amao JO and Awoyemi TT 2009 Determinants of adoption of improved rice varieties and its impact on farmers poverty level in Iwo agriculural development programme of Ogun State. Nigerian journal of rural sociology 9(1):1-8

Asumaghu GN and Nwosu KI 2006Tha cassava sector and backword intergration in sustaining the raw material requirement of existing and emerging agro-sallied enterprises in Nigeria. Proceedings of the $40^{\text {th }}$ Annual Conference of the Agricultural Society of Nigeria (ASN) held at NRCRI, Umidike, Abia state Nigeria:116-119.

Benor D 1984 Agricultural Extension: The training and visit system. A World Bank Publication. p.7Baxter, Michael W. P.Benor, Daniel (1984): Training and visit extension World Bank (Washington, D.C., U.S.A.)

Ejembi EP, Omoregbee FE and Ejembi SA 2006 Farmers' Assessment of the Training and Visit Extension System in Central Nigeria: Evidence from BarkinLadi,

Ekumankama OO 2000 Farmers level of satisfaction with formal agricultural information source in Umuahia, Abia state, Nigeria. Journal of sustainable Agriculture and Environment. MicheakOkpara University of Agriculture , Umudike. 2(2): 257-263

FAO and IFAD 2001 The global Cassava development strategy and implementation plan, Rome: (1):1-70. 
FAO and IFAD 2001 The global Cassava development strategy and implementation plan, Rome: (1):1-70.

Igben MS 1988 The Nigerian farmer and agricultural institutions: An assessment. Ibadan: Nigerian Institute of Social and Economic Research (NISER).

Imonikhe GA 2004 Impact of Katsina State Agriculture and community development project on income and productivity of farmers. Unpublished Ph.D

Omonona BT, Oni OA and Uwagboe AO 2006 Adoption of improved Cassava varieties and its welfare impact on rural farming households in Edo State Nigeria. Nigerian Journal of Agriculture and Food Information.7 (1): $39-55$

Thesis, Department of Agric. Economics \& Rural Sociology, Ahmadu Bello University, Zaria, Nigeria. p.59

Yahaya MK and Olayide BR 2002 Effectiveness of contact farmers' strategy in Oyo state ADP. Administrative lessons for poverty alleviation in agricultural technology transfer. Proceedings of the 6th Annual National Conference of the Agricultural Extension Society of Nigeria (AESON), 10th-12th April: 247-253. 